\title{
MORPHOMETRIC, INSTRUMENTAL AND LABORATORY PARAMETERS OF FEMALE RATS WITH EXPERIMENTAL METABOLIC SYNDROME
}

\author{
๑O. A. Hrygorieva, Y. V. Korotchuk \\ Zaporizhzhia State Medical University
}

\begin{abstract}
SUMMARY. The aim of the study - to learn the dynamics of changes of morphometric, instrumental and laboratory parameters in mature females rats with experimental metabolic syndrome.

Material and Methods. 20 females of white, mature laboratory rats, aged 18-20 months were divided into 2 groups. The first one is an experimental group: 13 female rats with experimental metabolic syndrome; the second one - control group: 7 intact rats, with standard food and water regime. When working with animals, the standards of the Council of Europe Bioethics Convention 1997, the European Convention for the Protection of Vertebrate Animals were observed. Instruments used during scientific research were subject to metrological control.

The simulation of the metabolic syndrome occurred during 60 days. The females supported a special high-calorie diet (grain with margarine $82 \%$ milk fat, corn and sunflower seeds). The water regime included a $20 \%$ solution of fructose and regular water ad libitum, with change every other day. Also, during the first and the fourth weeks of the experiment, the female daily subcutaneously administered Dexamethasone solution at a dosage of $0.1 \mathrm{mg} / \mathrm{kg}$.

Results. Since the beginning of the experiment, female rats who received a special high-calorie diet showed a statistically significant increase in all morphometric and instrumental indexes compared to similar rats in the control group. An increase in body weight in the experimental group was found to be $28.93 \%$ higher than the original weight, was observed arterial hypertension $(141 / 85 \pm 5) \mathrm{mmHg}$, dyslipidemia: elevated total cholesterol $(5.37 \pm 0.33) \mathrm{mmol} / \mathrm{L}$ and TG $(2.55 \pm 0.24) \mathrm{mmol} / \mathrm{L}$; elevated level glucose $(8.52 \pm 0.17) \mathrm{mmol} / \mathrm{L}$. The above indicators are criteria indicating the presence of metabolic syndrome in animals under study.

Conclusions. The proposed model of experimental metabolic syndrome, which includes subcutaneous administration of Dexamethasone solution at a dosage of $0.1 \mathrm{mg} / \mathrm{kg}$ in the first and the fourth weeks of experiment, with a special high calorie diet and a $20 \%$ solution of fructose, is an effective way to reproduce the metabolic syndrome in small rodents.

KEY WORDS: rat; obesity; metabolic syndrome; arterial blood pressure; dyslipidemia.
\end{abstract}

Introduction. The problem of prevention and treatment of metabolic syndrome (MS) is a topical problem of present time [1]. It is proved that obesity, especially during pregnancy, is one of the main mechanisms for the development of MS, which is an important problem of today and is becoming a worldwide epidemic [2]. In Europe, obesity is detected in more than $30 \%$ of patients, and in excess of $50 \%$ there is overweight [3]. Obesity is an established risk factor for pregnancy complications, an increase in the risk of gestational diabetes and preeclampsia [4].

According to some reports, the MS is found in 20-25\% of adult population, with women -2 times more often [5]. Some studies have shown that it is the body weight of a mother during pregnancy that can be a trigger, which in the future leads to metabolic disorders in offsprings $[6,7]$. Over the past decades, obesity in pregnant women has doubled [8], and an increased body mass index is threatening an increase in gestational age of pregnancy [9]. Thus, physicians pay more attention to pregnant women with overweight and obesity.

The modeling of experimental MS in animals demonstrates that the mother's obesity "programs" the offspring for excess body weight [6]. However, the peculiarities of changes in laboratory-instrumental and morphometric indices in animals require more in-depth study.
The aim of this study - to evaluate the dynamics of changes of morphometric, instrumental and laboratory parameters in mature female rats with experimental metabolic syndrome.

Material and Methods. The work was performed on 20 females of white, mature laboratory rats, aged 18-20 months that were divided into 2 groups. The first one is an experimental group: 13 female rats with experimental metabolic syndrome; the second one - control group: 7 intact rats, with standard food and water regime. When working with animals, the standards of the Council of Europe Bioethics Convention 1997, the European Convention for the Protection of Vertebrate Animals were observed. Instruments used during scientific research were subject to metrological control.

Rats were kept in vivarium, 2-3 individuals in a cage. The simulation of the metabolic syndrome occurred during 60 days. The females supported a special high-calorie diet (grain with margarine $82 \%$ milk fat, corn and sunflower seeds). The water regime included a $20 \%$ solution of fructose and regular water ad libitum, with change every other day. Also, during the first and the fourth weeks of the experiment, the female daily subcutaneously administered Dexamethasone solution at a dosage of $0.1 \mathrm{mg} / \mathrm{kg}$.

On the $1 \mathrm{st}$, 30 th, and 60 th day of the experiment, the females of both groups underwent examination 
Огляди літератури, оригінальні дослідження, погляд на проблему, випадок з практики, короткі повідомлення of the morphometric parameters: measuring the mass and body length, calculating the body mass index (BMl: body mass ratio in grams to square of body length in centimeters square) and the Lee index (the ratio of the cubic root mass of the body in grams to the body length in centimeters).

Instrumental and laboratory studies of females were carried out on the 60th day, from the beginning of the experiment, on the basis of the medical laboratory center of the Zaporizhzhia State Medical

University and the veterinary clinic "Dobrodiy" (Zaporizhzhia, 165 Krugova St., the license of the main department of veterinary medicine in Zaporizhzhia region AB No.527006).

The level of systolic and diastolic blood pressure (BP) was determined by the system of non-invasive blood pressure measurement of Blood Pressure Analysis Systems TM BP-2000 Series II (Visitech Systems, USA) with automatic temperature control in the immobilization tunnel.

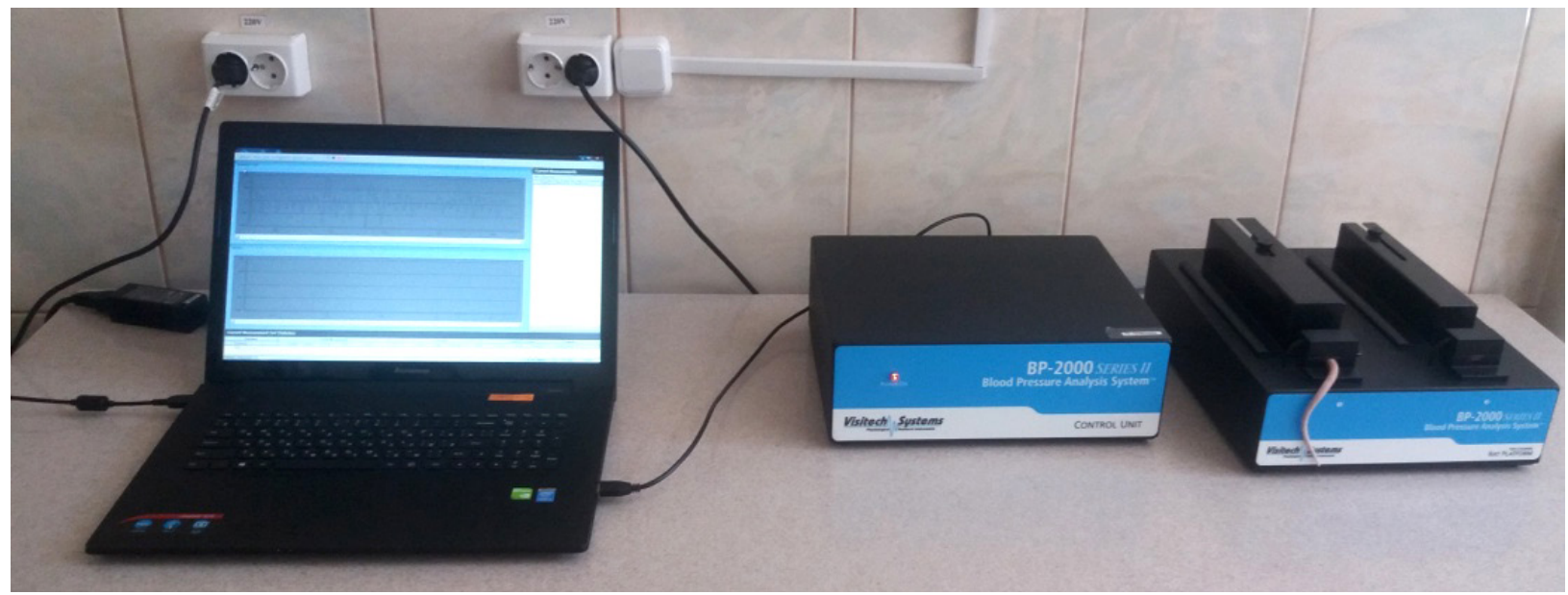

Fig.1. Definition of blood pressure using the system of non-invasive blood pressure measurement Blood Pressure Analysis Systems TM BP-2000 Series II.

To measure the BP of rats, they were placed in special lockers equipped with a thermostatic platform, which provides constant temperature maintenance at $37-39^{\circ} \mathrm{C}$. Catchers for animals were lightproof, which provides a faster reduction of stress response and animal reassurance. The average time of the registration of blood pressure was 3-7 minutes, during which 3-5 preliminary and 3-5 control measurements were performed with the calculation of mean values of heart rate, systolic and diastolic pressure [10].

Blood was sedimentation for at least 30 minutes at $38{ }^{\circ} \mathrm{C}$ and centrifuged for $10 \mathrm{~min}$. at $1000 \mathrm{~g}$, followed by serum selection. The content of total cholesterol, triglycerides and glucose in the serum of rats was determined using a biochemical analyzer
HTI BioChem SA (USA) and standard test kits (High Technology Inc, USA).

Obtained data were statistically processed using Windows XP Excel 2007 (Microsoft Office, USA) and "Statistica for Windows 6.0" (StatSoftInc., №AXXR712D833214FAN5). The certainty difference of data of experimental and control groups was assessed by Student's test. The compared results considered such, that for certain differ at $p<0.05$ [11].

Results and Discussion. At the start of the experiment, the body weight of the control group rats was $(250.14 \pm 4.45) \mathrm{g}$, BMI was $(0.51 \pm 0.01)$, and the Lee index was $(0.28 \pm 0.01)$. Morphometric indices of experimental group females on the first day of observation did not differ statistically from the control group (Table 1).

Table 1. Morphometric indices of the experimental and control group of rats $(\mathrm{M} \pm \mathrm{m})$

\begin{tabular}{|l|c|c|c|c|}
\hline \multicolumn{1}{|c|}{ Animal group } & Experiment Day & Body weight, $g$ & BMI, $\mathrm{g} / \mathrm{cm}^{2}$ & Index Lee \\
\hline \multirow{3}{*}{ Control $(n=7)$} & $1^{\text {st }}$ day & $250.14 \pm 4.45$ & $0.51 \pm 0.01$ & $0.28 \pm 0.01$ \\
\cline { 2 - 5 } & $30^{\text {th }}$ day & $266 \pm 6.19$ & $0.54 \pm 0.01$ & $0.29 \pm 0.01$ \\
\cline { 2 - 5 } & $60^{\text {th }}$ day & $276.85 \pm 4.22$ & $0.57 \pm 0.02$ & $0.29 \pm 0.01$ \\
\hline \multirow{2}{*}{$\begin{array}{l}\text { Metabolic } \\
\text { syndrome ( } n=13)\end{array}$} & $1^{\text {st }}$ day & $254.69 \pm 7.35$ & $0.52 \pm 0.01$ & $0.28 \pm 0.01$ \\
\cline { 2 - 5 } & $30^{\text {th }}$ day & $306.53 \pm 4.33^{*}$ & $0.63 \pm 0.01^{*}$ & $0.3 \pm 0.01$ \\
\cline { 2 - 5 } & $60^{\text {th }}$ day & $358.61 \pm 7.55^{*}$ & $0.74 \pm 0.02^{*}$ & $0.32 \pm 0.01^{*}$ \\
\hline
\end{tabular}

Notes. * - the results are considered to be reliable at $\mathrm{p}<0.05 ; \mathrm{n}$ - the number of animals in the group. 
Огляди літератури, оригінальні дослідження, погляд на проблему, випадок з практики, короткі повідомлення

On the 30th day of observation in the control group females body mass was $(266 \pm 6.19) \mathrm{g}$, which was an increase in weight of $5.94 \%$. As a result, the value of BMI and Lee index increased. In the animals of the experimental group, one month later, from the beginning of the experiment, an increase in body weight was observed for $16.88 \%$, which was $(306.53 \pm 4.33$ g. An increase in BMl was observed, while the Lee index was not statistically different from that of the control group (Table 1).

Since the introduction model into the experimental metabolic syndrome was calculated for
60 days, therefore, after this period, the females were more closely monitored. The morphometric indices of the control group's females showed an increase in weight of only $9.64 \%$, which was $(276.85 \pm 4.22) \mathrm{g}$. The BMI increased, while the Lee index remained at the previous level (0.29 \pm 0.01$)$. Measurement of blood pressure (Figure 1) showed a value of $(122 / 78 \pm 4) \mathrm{mm} \mathrm{Hg}$.

The laboratory parameters of the control group showed the following results: total cholesterol (CT) was $(2.42 \pm 0.21) \mathrm{mmol} / \mathrm{L}$, triglycerides (TG) $(0.77 \pm$ 0.06) $\mathrm{mmol} / \mathrm{L}$, glucose $(4.75 \pm 0.28) \mathrm{mmol} / \mathrm{L}$ (Table 2$)$.

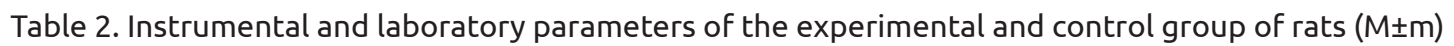

\begin{tabular}{|c|c|c|}
\hline \multirow{2}{*}{ Indexes } & \multicolumn{2}{|c|}{ Animal group } \\
\cline { 2 - 3 } & Control $(\mathrm{n}=7)$ & Experiment $(\mathrm{n}=13)$ \\
\hline $\mathrm{BP}, \mathrm{mmHg}$ & $122 / 78 \pm 4$ & $141 / 85 \pm 5^{*}$ \\
\hline $\mathrm{CT}, \mathrm{mmol} / \mathrm{L} \quad 2.42 \pm 0.21$ & $5.37 \pm 0.33^{*}$ \\
\hline TG, $\mathrm{mmol} / \mathrm{L}$ & $0.77 \pm 0.06$ & $2.55 \pm 0.24^{*}$ \\
\hline Glucose, $\mathrm{mmol} / \mathrm{L}$ & $4.75 \pm 0.28$ & $8.52 \pm 0.17^{*}$ \\
\hline
\end{tabular}

Notes.* - the results are considered to be reliable at $p<0.05 ; n$ - the number of animals in the group.

At the time of the completion of the observation, all the morphometric parameters of the experimental group's females, who received a special diet for two months, were significantly higher in comparison with those of the control group of rats. Thus, an increase in body weight was noted for $28.93 \%$, which is equal to $(358.61 \pm 7.55) \mathrm{g}$.

Instrumental (blood pressure measurements) and laboratory tests (determination of CT, TG and glucose) of the experimental group of rats showed a statistically significant increase of all indexes in comparison with similar parameters of the control group (Table 2). Thus, blood pressure was $(141 / 85 \pm 8) \mathrm{mmHg}$ vs. $(122 / 78 \pm 4) \mathrm{mm} \mathrm{Hg}, \mathrm{CT}(5.37 \pm 0.33) \mathrm{mmol} / \mathrm{L}$, TG $(2.55 \pm 0.24) \mathrm{mmol} / \mathrm{L}$, glucose $(8.52 \pm 0.17) \mathrm{mmol} / \mathrm{L}$.

Thus, since the beginning of the experiment, females who received a special high-calorie diet showed a statistically significant increase in all morphometric indexes compared to similar rats in the control group. An increase in body weight in the experimental group was found to be $28.93 \%$ higher than the original weight, which was $(358.61 \pm 7.55) \mathrm{g}$, respectively, on the 60th day of the experiment. However, in control animals the index of body weight increased for $9.64 \%$ of the original mass $(276.85 \pm 4.22) \mathrm{g}$ on the 60 th day, respectively).

The use of indicators such as BMI and the Lee index allowed objectively estimating the presence of obesity in the animals under study. With BMI, obesity was defined as greater than $0.68 \mathrm{~g} / \mathrm{cm} 2$ [12]. The values of the Lee index had the following gradations: 0.3 was considered a limit, $>0.3$ - obesity is, $<0.3-$ no obesity [13].
Analyzing the dynamics of the above-mentioned indicators, a statistically significant increase in BMI and Lee index in the experimental group during the entire observation period compared to the control group of rats was observed. Females who received a special high calorie diet for 60 days had an BMI of $(0.74 \pm 0.02)$ and $a$ Lee index of $(0.32 \pm 0.01)$ at the end of the experiment. At the same time, control rats, with a standard diet, had respectively a BMI $(0.57 \pm$ $0.02)$ and a Lee index $(0.29 \pm 0.01)$. Thus, the results of the above-mentioned morphometric indices testify to obesity in the experimental group's females.

In the case of instrumental and laboratory studies, against the control group's reference values, at animals of the experimental group there was a hypertension $(141 / 85 \pm 5) \mathrm{mm} \mathrm{Hg}$, dyslipidemia (total cholesterol level $(5.37 \pm 0.33) \mathrm{mmol} / \mathrm{L}$, TG $(2.55 \pm$ $0.24) \mathrm{mmol} / \mathrm{L})$, elevated glucose $(8.52 \pm 0.17) \mathrm{mmol} / \mathrm{L}$.

Some studies have indicated that the most common combination of metabolic syndrome is the combination of obesity, arterial hypertension, hypercholesterolemia and insulin resistance $[14,15]$. Taking into account the morphometric, instrumental and laboratory parameters of experimental group rats, there are grounds to assert that the used model for introduction into the metabolic syndrome is effective, and females are in a metabolic syndrome.

Conclusions. 1. Increase of body weight of female rats in the experimental group for $28.93 \%$, against the background of statistically significant increase of other morphometric indices in comparison with similar values of rats of the control group (BMT $(0.74 \pm 0.02)$, Lee index $(0.32 \pm 0.01)$ vs. $(0.57 \pm 0.02)$ and 
Огляди літератури, оригінальні дослідження, погляд на проблему, випадок з практики, короткі повідомлення

$(0.29 \pm 0.01)$ respectively), gives grounds to talk about the presence of obesity in the experimental group.

2. Instrumental and laboratory indices have shown that in the experimental group of female rats arterial hypertension $(141 / 85 \pm 5) \mathrm{mmHg}$, dyslipidemia: elevated total cholesterol $(5.37 \pm 0.33) \mathrm{mmol} / \mathrm{L}$ and TG (2.55 \pm 0.24$) \mathrm{mmol} / \mathrm{L}$; high glucose level $(8.52 \pm 0.17) \mathrm{mmol} / \mathrm{L}$ have been defined. The above indicators are criteria indicating the presence of a metabolic syndrome in animals under study.

\section{LIST OF LITERATURE}

1. Shalitin S. Obesity, metabolic syndrome and nutrition. Nutrition and growth / S. Shalitin, T. Battelino, L. A. Moreno; B. Koletzko, R. Shamir, D. Turck, M. Phillip (Eds.) // World. Rev. Nutr. Diet. Basel, Karger, 2019. Vol. 119. - P. 13-42. DOI: 10.1159/000494306.

2. Obesity in pregnancy as a model to identify women at risk for later metabolic syndrome / C. Neri, C. Di Cesare, A. Labianca [et al.] // Gynecol. Endocrinol. - 2018. Vol. 34 (1). - P. 28-31.

3. Michou M. Low health literacy and excess body weight: A systematic review / M. Michou, D. B. Panagiotakos, V. Costarelli // Cent. Eur. J. Public Health. - 2018. Vol. 26 (3). - P. 234-241.

4. Metabolic syndrome in pregnancy and risk for adverse pregnancy outcomes: A prospective cohort of nulliparous women / J. A. Grieger, T. Bianco-Miotto, L. E. Grzeskowiak [et al.]//PLoS Med.-2018. - Vol. 15 (12).-e1002710.

5. Higher infant body fat with excessive gestational weight gain in overweight women / H. R. Hull, J. C. Thornton, Y. Ji [et al.] // Am. J. Obstet. Gynecol. - 2011. Vol. 205 (3). - P. 211-e1.

6. Korotchuk Y. V. Dynamics of the mass-growth indexes of rats, got from mothers with experimental metabolic syndrome / Y. V. Korotchuk // German Sci. Herald. 2019. - Vol. 2. - P. 35-38.

7. Thunga S. Obesity in pregnancy / S. Thunga, S. Bampoe // Obstetric Anesthesiology: A Case-Based Approach / In: T. Husain, R. Fernando, S. Segal (Eds.). - Cambridge: Cambridge University Press, 2019. - P. 73-80. DOI: https:// doi.org/10.1017/9781316155479.

\section{REFERENCES}

1. Shalitin, S., Battelino, T., \& Moreno, L.A. (2019). Obesity, metabolic syndrome and nutrition. Nutrition and Growth. B. Koletzko, R. Shamir, D. Turck, M. Phillip (Eds.). World. Rev. Nutr. Diet. Basel, 119, 13-42. Karger: DOI: https://doi.org/10.1159/000494306.

2. Neri, C., Di Cesare, C., Labianca, A., Viggiano, M., Caruso, A., \& Paradisi, G. (2018). Obesity in pregnancy as a model to identify women at risk for later metabolic syndrome. Gynecol. Endocrinol., 34 (1), 28-31.

3. Michou, M., Panagiotakos, D.B., \& Costarelli, V. (2018). Low health literacy and excess body weight: A systematic review. Cent. Eur. J. Public Health, 26 (3), 234-241.
3. The proposed model of experimental metabolic syndrome, which includes subcutaneous administration of Dexamethasone solution at a dosage of $0.1 \mathrm{mg} / \mathrm{kg}$ in the first and the fourth weeks of experiment, with a special high calorie diet and a $20 \%$ solution of fructose, is an effective way to reproduce the metabolic syndrome in small rodents.

Conflict of interest. The authors declare no conflict of interest.

8. Siega-Riz A. M. The implications of maternal overweight and obesity on the course of pregnancy and birth outcomes / A. M. Siega-Riz, B. Laraia // Matern. Child Health J. - 2006. - Vol. 10 (1). - P. 153-156.

9. Association of BMI and interpregnancy BMI change with birth outcomes in an Australian obstetric population: a retrospective cohort study / C. R. Knight-Agarwal, L. T. Williams, D. Davis [et al.]//BMJ Open.-2016.-Vol.6. -e010667.

10. Современные подходы и новые методические возможности в оценке функционального состояния мелких лабораторных животных / Ю. М. Колесник, О. В. Ганчева, А. В. Абрамов [та ін.] // Патологія. - 2017. № 14 (3). - C. 364-370.

11. Glantz S. A. Primer of biostatistics / S. A. Glantz 7th ed. - New York, NY : McGraw-Hill, 2012. - P. 327.

12. Anthropometrical parameters and markers of obesity in rats / E. L. Novelli, Y. S. Diniz, C. M. Galhardi [et al.] // Lab. Anim. - 2007. - Vol. 41 (1). - P. 111-119.

13. Effect of obesity on rat reproduction and on the development of their adult offspring / K. E. D. Campos, G. T. Volpato, I. D. M. P. Calderon [et al.] // Braz. J. Med. Biol. Res. - 2008. - Vol. 41 (2). - P. 122-125.

14. High risk of metabolic syndrome after delivery in pregnancies complicated by gestational diabetes / Y. Shen, W. Li, J. Leng [et al.] // Diabetes Res. Clin. Pract. - 2019. Vol. 150. - P. 219-226.

15. Metabolic and hypertensive complications of pregnancy in women with nephrolithiasis / J. S. Tangren, C. E. Powe, J. Ecker [et al.] // Clin. J. Am. Soc. Nephrol. 2018. - Vol. 13 (4). - P. 612-619.

4. Grieger, J.A., Bianco-Miotto, T., Grzeskowiak, L.E., Leemaqz, S.Y., Poston, L., McCowan, L.M., \& Roberts, C.T. (2018). Metabolic syndrome in pregnancy and risk for adverse pregnancy outcomes: A prospective cohort of nulliparous women. PLoS Med., 15 (12), e1002710.

5. Hull, H.R., Thornton, J.C., Ji Y., Paley, C., Rosenn, B., Mathews, P., \& Gallagher, D. (2011). Higher infant body fat with excessive gestational weight gain in overweight women. Am. J. Obstet. Gynecol., 205 (3), 211-e1.

6. Korotchuk, Y.V. (2019). Dynamics of the mass-growth indexes of rats, got from mothers with experimental metabolic syndrome. German Sci. Herald, 2, 35-38. 
Огляди літератури, оригінальні дослідження, погляд на проблему, випадок з практики, короткі повідомлення

7. Thunga, S., \& Bampoe, S. (2019). Obesity in pregnancy. Obstetric Anesthesiology: A Case-Based Approach. Husain T., Fernando R., Segal S. (Eds.). Cambridge: Cambridge University Press. DOI: https://doi.org/10.1017/9781316155479.

8. Siega-Riz, A.M., \& Laraia, B. (2006). The implications of maternal overweight and obesity on the course of pregnancy and birth outcomes. Matern. Child Health J., 10 (1), 153-156.

9. Knight-Agarwal, C.R., Williams, L.T., \& Davis, D. (2016). Association of BMI and interpregnancy BMI change with birth outcomes in an Australian obstetric population: a retrospective cohort study. BMJ Open, 6, e010667.

10. Kolesnyk, Y.M., Hancheva, O.V., Abramov, A.V., Kolesnyk, M.Y., Ivanenko, T.V., Tishchenko, S.V., \& Fedotova, M.I. (2017). Suchasni pidkhody i novi metodychni mozhlivosti v otsiniuvanni funktsionalnoho stanu dribnykh laboratornykh tvaryn [Current approaches and new methodological possibilities in the assessment of the functional state of small laboratory animals]. Patolohiia - Pathology, 14 (3), 364-370 [in Ukrainian].
11. Glantz, S.A. (2012). Primer of biostatistics. 7th ed. New York, NY: McGraw-Hill.

12. Novelli, E.L., Diniz, Y.S., Galhardi, C.M., Ebaid, G.M., Rodrigues, H.G., Mani, F., ..., \& Novelli Filho, J.L. (2007). Anthropometrical parameters and markers of obesity in rats. Lab. Anim., 41 (1), 111-119.

13. Campos, KE.D., Volpato, G.T., Calderon, ID.MP., Rudge, MV.C., \& Damasceno, D.C. (2008). Effect of obesity on rat reproduction and on the development of their adult offspring. Braz. J. Med. Biol. Res., 41 (2), 122-125.

14. Shen, Y., Li, W., Leng, J., Zhang, S., Liu, H., Li, W., \& Yang, X. (2019). High risk of metabolic syndrome after delivery in pregnancies complicated by gestational diabetes. Diabetes Res. Clin. Pract., 150, 219-226.

15. Tangren, J.S., Powe, C.E., Ecker, J., Bramham, K., Ankers, E., Karumanchi, S.A., \& Thadhani, R. (2018). Metabolic and hypertensive complications of pregnancy in women with nephrolithiasis. Clin. J. Am. Soc. Nephrol., 13 (4), 612-619.

\title{
МОРФОМЕТРИЧНІ, ІНСТРУМЕНТАЛЬНІ ТА ЛАБОРАТОРНІ ПОКАЗНИКИ ЩУРІВ-САМИЦЬ ІЗ ЕКСПЕРИМЕНТАЛЬНИМ МЕТАБОЛІЧНИМ СИНДРОМОМ
}

๑О. А. Григор'єва, $€$. В. Коротчук

\author{
Запорізький державний медичний університет
}

РЕзЮМЕ. Мета - вивчити динаміку змін морфометричних, інструментальних та лабораторних показників у статевозрілих самиць щурів із експериментальним метаболічним синдромом.

Матеріал і методи. О6'єктом дослідження стали 20 самиць білих статевозрілих лабораторних щурів віком 1820 місяців, котрі були поділені на 2 групи. Перша - експериментальна група: 13 самиць зі змодельованим метаболічним синдромом; друга - контрольна група: 7 інтактних щурів, зі стандартним харчовим та водним режимом. При роботі із тваринами було дотримано нормативів Конвенції з біоетики Ради Європи 1997 р., Європейської конвенції про захист хребетних тварин. Прилади, що використовувалися під час наукових досліджень, підлягали метрологічному контролю.

Моделювання метаболічного синдрому відбувалось протягом 60 днів. Самиці перебували на спеціальній висококалорійній дієті (зерно з маргарином молочним 82 \% жирності, кукурудза та насіння соняшника). Водний режим включав 20 \% розчин фруктози та звичайну воду ad libitum, зі зміною через день. Також протягом першого та четвертого тижнів експерименту самицям щоденно підшкірно вводили розчин дексаметазону в дозуванні 0,1мг/кг.

Результати. 3 моменту початку експерименту у самок, котрі отримували спеціальну висококалорійну дієту, відмічалось статистично достовірне збільшення усіх морфометричних та інструментальних показників, порівняно з аналогічними показниками щурів контрольної групи. В експериментальній групі було констатовано збільшення маси тіла, порівняно із початковою масою, на 28,93 \%, спостерігались артеріальна гіпертензія (141/85 \pm 5 мм

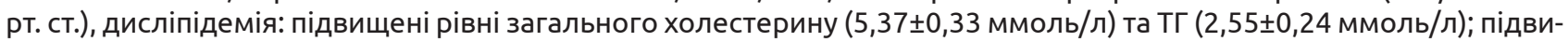
щений рівень глюкози (8,52 0,17 ммоль/л). Надлишкова маса тіла, підвищений артеріальний тиск та зміни лабораторних показників у експериментальних самиць підтверджували наявність метаболічного синдрому.

Висновки. Запропонована модель введення в експериментальний метаболічний синдром, котра включає щоденне підшкірне введення розчину дексаметазону у дозуванні 0,1 мг/кг протягом першого та четвертого тижнів експерименту, зі спеціальною висококалорійною дієтою та 20 \% розчином фруктози, $\epsilon$ ефективним способом відтворення метаболічного синдрому на дрібних гризунах.

КЛючОВІ СлОВА: щур; ожиріння; метаболічний синдром; артеріальна гіпертензія; дисліпідемія. 
Огляди літератури, оригінальні дослідження, погляд на проблему, випадок з практики, короткі повідомлення

\title{
МОРФОМЕТРИЧЕСКИЕ, ИНСТРУМЕНТАЛЬНЫЕ И ЛАБОРАТОРНЫЕ ПОКАЗАТЕЛИ КРЫС-САМОК ПРИ ЭКСПЕРИМЕНТАЛЬНОМ МЕТАБОЛИЧЕСКОМ СИНДРОМЕ
}

ОЕ. А. Григорьева, Е. В. Коротчук

\author{
Запорожский государственный медицинский университет
}

РЕЗЮМЕ. Цель - изучить динамику изменений морфометрических, инструментальных и лабораторных показателей у половозрелых самок крыс с экспериментальным метаболическим синдромом.

Материал и методы. Объектом исследования стали 20 самок белых половозрелых лабораторных крыс в возрасте 18-20 месяцев, которые были поделены на 2 группы. Первая - экспериментальная группа: 13 самок с моделированным метаболическим синдромом; вторая - контрольная группа: 7 интактных крыс со стандартным пищевым и водным режимами. При работе с животными были соблюдены нормативы Конвенции по биоэтике Совета Европы 1997 г., Европейской конвенции о защите позвоночных животных. Приборы, которые использовались при научных исследованиях, подлежали метрологическому контролю.

Моделирование метаболического синдрома происходило в течение 60 дней. Самки получали специальную высококалорийную диету (зерно с маргарином молочным 82 \% жирности, кукуруза и семечки подсолнуха). Водный режим был представлен 20 \% раствором фруктозы и обычной водой ad libitum, со сменой через день. Также на первую и четвертую недели эксперимента самкам ежедневно подкожно вводили раствор дексаметазона в дозе $0,1 \mathrm{Mr} / \mathrm{кг}$.

Результаты. С момента начала эксперимента у самок, которые получали специальную высококалорийную диету, отмечалось статистически достоверное увеличение всех морфометрических и инструментальных показателей, по сравнению с аналогичными показателями крыс контрольной группы. Было констатировано увеличение массы тела в экспериментальной группе, по сравнению с начальной массой, на 28,93 \%, наблюдались артериальная гипертензия (141/85 \pm 5 мм), дислипидемия: повышенный уровень общего холестерина $(5,37 \pm 0,33$ ммоль/л) и

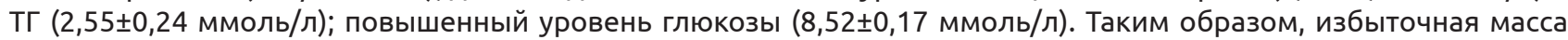
тела, повышенное артериальное давление и изменения лабораторных показателей экспериментальных самок подтверждали наличие метаболического синдрома.

Выводы. Предложена модель по введению в экспериментальный метаболический синдром, которая предусматривает ежедневное подкожное введение раствора дексаметазона в дозе 0,1 мг/кг в течение первой и четвертой недель эксперимента, со специальной высококалорийной диетой и 20 \% раствором фруктозы, является эффективным способом моделирования метаболического синдрома на мелких грызунах.

КЛЮЧЕВЫЕ СЛОВА: крыса; ожирение; метаболический синдром; артериальная гипертензия; дислипидемия.

Отримано 11.08 .2020 